\title{
Goniometric study of young and adult Saanen goats
}

\section{Estudo goniométrico de caprinos Saanen jovens e adultos}

\author{
Jomel Francisco dos Santos ${ }^{1 *}$; Ueliton Assis de Lima²; Amara Maria de Sousa \\ Barbosa $^{2}$; Thiago Arcoverde Maciel $^{3}$; Everton Diogo de Farias Firmino4; \\ Matheus Castro Franco ${ }^{5}$; Paulo José Duarte-Neto ${ }^{6}$; Daniela Oliveira ${ }^{7}$
}

\begin{abstract}
Using the goniometric method, it is possible to take measures of extension, flexion, abduction, and adduction of a synovial joint. The aim of this study was to use goniometry to compare flexion and extension of fore and hind limbs of Saanen goats at different ages. Flexion and extension angles of the shoulder, elbow, and carpus joints, as well as of the thigh, stifle, and tarsus joints, were measured using a standard goniometer on 10 six-month-old goats and on 15 three-year-old goats. The range of motion was reduced in all joints of the adult animals compared to that of the younger animals, but the difference was statistically significant only for the shoulder, elbow, stifle, and tarsus. It was noted that the greater muscle volume of adult animals influenced the flexion capacity of limbs (statistically verified for all joints), whereas young animals reached a more complete flexion with smaller angles than in adults. Therefore, we have shown that age affects goniometric measurements of synovial joints in Saanen goats. Such data may be useful in evaluation of joints in other goats.
\end{abstract}

Key words: Flexion. Extension. Goniometer. Young. Adult. Caprine.

\section{Resumo}

Por meio do método goniométrico é possível tomar medidas de extensão e de flexão, abdução e adução de uma articulação sinovial. O objetivo deste estudo foi comparar os dados goniométricos dos membros torácicos e pélvicos de cabras da raça Saanen em diferentes idades quando submetidos a movimentos de extensão e flexão. Para tanto, foram utilizadas 10 cabras de seis meses de idade e 15 de três anos para medir os ângulos de flexão e extensão das articulações do ombro, cotovelo e carpo, bem como das articulações da coxa, joelho e do tarso com a utilização de um goniômetro universal. A amplitude de movimento foi reduzida em animais adultos em todas as articulações, mas estatisticamente significativa no ombro, cotovelo, joelho e tarso. Durante as medições verificou-se que o volume maior do músculo de animais adultos influenciou a capacidade de flexão dos membros, estatisticamente mostrado em todas as articulações estudadas. Por outro lado, os animais jovens atingiram flexão mais completa, com ângulos

${ }^{1}$ Prof. M.e, Curso de Medicina Veterinária do Instituto Federal de Educação, Ciência e Tecnologia do Amazonas, Campus Manaus, Zona Leste, IFAM/CMZL, Manaus, AM, Brasil. E-mail: jomel.santos@ifam.edu.br

2 Técnicos em Anatomia e Necropsia, Curso de Medicina Veterinária, Universidade Federal Rural de Pernambuco, Unidade Acadêmico de Garanhuns, UFRPE/UAG, Garanhuns, PE, Brasil. E-mail: uelitonassis@hotmail.com; amara@uag.ufrpe.br

${ }^{3}$ Prof., Assistente de Clínica e Cirurgia de Equídeos da Universidade Federal de Campina Grande, Unidade Acadêmica de Medicina Veterinária, UFCG/UAMV, Campina Grande, PB, Brasil. E-mail: arcoverde.thiago@hotmail.com

${ }^{4}$ Discente de Pós-Graduação no Programa de Ciência Animal Tropical, UFRPE, Recife, PE, Brasil. E-mail: evertondiogoff@ hotmail.com

${ }_{5}^{5}$ Médico Veterinário, Universidade Federal do Espírito Santo, Campus de Ciências Agrárias e Engenharias, UFES/CCAE, Alegre, ES, Brasil. E-mail: matheusr2@yahoo.com.br

${ }^{6}$ Prof. Adjunto, Departamento de Estatística e Informática, UFRPE, Recife, PE, Brasil. E-mail: pjneto@ufrpe.br

${ }^{7}$ Prof a Associada, Curso de Medicina Veterinária, UFRPE, Unidade Acadêmica de Garanhuns, UFRPE/UAG, Garanhuns, PE, Brasil. E-mail: danisjc6@yahoo.com.br

* Author for correspondence 
menores do que em adultos. Portanto, houve diferenças entre as idades estatisticamente significativas nos valores goniométricos dos membros torácicos e pélvicos quando esses foram submetidos a movimentos de flexão e extensão. Confirma-se, pois, que a idade interfere nos valores goniométricos das articulações sinoviais dos animais da raça Saanen e esses dados poderão ser utilizados na avaliação articular de caprinos.

Palavras-chave: Flexão. Extensão. Goniometria. Jovem. Adulto. Cabras.

\section{Introduction}

In anatomy, the joint is defined as the connection of two or more bones or cartilage and other tissue, regardless of the presence or absence of movement. Structural and functional characteristics further define the joint as fibrous, cartilaginous, or synovial (GETTY et al., 1986; DUKES et al., 2007; COLVILLE; BASSERT, 2008; FRANDSON et al., 2011). A synovial joint, formerly known as diarthrosis, is the only one that allows free movements like sliding, adduction, abduction, flexion, and extension (COLVILLE; BASSERT, 2008; DYCE et al., 2010; FRANDSON et al., 2011). The movements made by the bones in this type of joint require complex structures in which sliding of the bone ends toward each other is facilitated by the action of a lubricating synovial fluid (DUKES et al., 2007). Such complex structures include the joint capsule, articular surfaces, joint cavity, articular cartilages, ligaments, discs, and meniscus (DUKES et al., 2007; DYCE et al., 2010).

Several methods exist to assess the range of motion in synovial joints. Kinematics requires complex equipment, and evaluates the geometry of the movement as well as the displacement speed and acceleration. Computerized photogrammetry requires digital photography and appropriate software. Goniometry, a statistical evaluation, has the advantages of simplicity and low cost (ALIEVI et al., 2004; GILLETTE; ANGLE, 2008; CONCEIÇÃO et al., 2012).

According to Batista et al. (2006), goniometry has been used widely during the twentieth century to measure joint range of motion, either in clinical cases or in scientific studies. Veterinarians, in particular, employ goniometry to assess the extent and progression of joint diseases, as well as response to an established treatment (GAIAD et al., 2011; CONCEIÇÃO et al., 2012). However, the use of goniometric measures in the treatment of certain diseases requires the establishment of standards for the characterization of normal joints (ARAÚJO et al., 2009).

Goniometric methods measure flexion and full extension, and thereby determine the range of motion. Therefore, goniometry can be useful in assessing changes after orthopedic surgery and during subsequent rehabilitation procedures that require prolonged joint immobilization which, in turn, can lead to muscle atrophy and a decreased range of motion (ALIEVI et al., 2004; ARAÚJO et al., 2009). Goniometry may also be useful for monitoring the emergence of osteoporosis and the development of osteoarthritis (UHTHOFF; JAWORSKI, 1978; LANGENSKIÖLD et al., 1979).

Joint diseases in goats are not uncommon, and may have a bacterial etiology (primarily associated with Mycoplasma mycoides), a viral etiology (primarily associated with caprine arthritisencephalitis virus (CAEV)), or a trauma etiology. Joint diseases decrease the productive life of affected individuals by limiting movement and decreasing joint amplitude through painful stimuli, thus causing the individual to have difficulty feeding with a subsequent loss of weight and low productivity (GREGORY et al., 2006).

The purpose of this study was to evaluate range of motion in joints of healthy young and adult Saanen goats, and thereby document normal parameters for subsequent evaluations of joint diseases in this species. 


\section{Material and Methods}

All procedures were approved by UFRPE Ethics Committee on Animal Use (License number 026/2015, Process number 23082.001091/2015).

Animals were selected after clinical examination according to Diffay et al. (2005), which emphasizes inspection and observation of articular and periarticular changes. No animals presented any clinical joint disease. Joint angles were measured in 15 healthy three-year-old Saanen goats (females, average weight $68.9 \pm 8.52 \mathrm{~kg}$ ) and in 10 healthy six-month-old females of the same breed (average weight of $27.6 \pm 14.92 \mathrm{~kg}$ ). The goats were housed on a breeding property in Pedra, State of Pernambuco, Brazil, and measurements were made in the handling corral.

Measurements were performed with the aid of a plastic standard goniometer, with the animals in station and the examiner manually moving the joints (shoulder, elbow, carpus, thigh, stifle, and tarsus) to maximum extension and flexion. Maximum extension and flexion were reached when the tissues offered resistance to the progression of movement. The goniometer was positioned in the joints according to Conceição et al. (2012), and all measurements were performed by the same investigator. Results were expressed in degrees as mean \pm standard deviation, and differences between age groups were assessed by Student's t-test ( $\mathrm{p}<$ 0.05; SAS version 8.2).

\section{Results}

Goniometric values of the joints showed no statistical difference between the antimeres.

Age did not affect maximum extension of shoulder joint (young, $144.20 \pm 9.25$; adult, 137.00 $\pm 17.12 ; \mathrm{p}>0.05)$. However, maximum flexion, also reflective of the range of motion, was significantly different $(p<0.05)$ for the shoulder joints between young and adult animals (flexion in young animals of $44.40 \pm 6.92$ versus $62.50 \pm 8.54$ in adults; range of motion in young animals of $99.80 \pm 12.90$ versus $74.50 \pm 18.61$ in adults).

The elbow joint (Figure 1A) showed agedependent differences in all parameters. Young goats presented elbow angles of $156.9 \pm 4.79$ in extension, $18.5 \pm 2.67$ in flexion, and $138.4 \pm 4.43$ in range of motion, whereas adult animals measured $148.07 \pm 14.59$ in extension, $26.4 \pm 7.76$ in flexion, and $121.67 \pm 19.74$ in range of motion.

The carpus joint was different only in flexion (young: $15.6 \pm 3.22$; adult: $21.43 \pm 3.67$ ). No agedependent differences were seen in carpus extension (young: $168.9 \pm 2.94$; adult: $167.73 \pm 10.84$ ) or in range of motion (young: $153.3 \pm 3.69$; adult: 146.3 $\pm 11.37)$.

For the thigh joint, only the maximum flexion showed a difference between ages (young: $17.4 \pm$ 7.51; adult: $25.2 \pm 13.74$ ). Extension and range of motion for the thigh joint were similar in both ages (Table 1).

The age-dependent difference in the range of motion of the stifle joint $(21.1 \pm 2.71$ in young goats versus $28.23 \pm 5.65$ in older goats) was mirrored by an age-dependent difference in flexion of the joint $(133.5 \pm 8.85$ versus $120.83 \pm 20.54)$.

The tarsus joint (Figure 1B) showed agedependent differences in extension (young: $167 \pm$ 4.23; adult: $162.27 \pm 11.87$ ), flexion (young: 19.8 \pm 2.97 ; adult: $27.33 \pm 7.71)$ and range of motion (young: $147.2 \pm 5.21$; adult: $134.93 \pm 13.25$ ). 
Table 1. Goniometric values (angle \pm standard deviation) of the shoulder, elbow, carpus, thigh, stifle, and tarsal joints of six-month old and three-year-old goats. Statistical analysis (p value) for comparison of angles in extension, flexion and range of motion between the ages.

\begin{tabular}{lllll}
\hline Joint & Movement & 6 months & 3 years & p \\
\hline Shoulder & Extension & $144.20 \pm 9.25$ & $137.00 \pm 17.12$ & 0.063 \\
& Flexion & $44.40 \pm 6.92$ & $62.50 \pm 8.54$ & $0.000^{*}$ \\
\multirow{3}{*}{ Elbow } & Range of motion & $99.80 \pm 12.90$ & $74.50 \pm 18.61$ & $0.000^{*}$ \\
& Extension & $156.9 \pm 4.79$ & $148.07 \pm 14.59$ & $0.020^{*}$ \\
& Flexion & $18.5 \pm 2.67$ & $26.4 \pm 7.76$ & $0.000^{*}$ \\
Carpus & Range of motion & $138.4 \pm 4.43$ & $121.67 \pm 19.74$ & $0.001^{*}$ \\
& Extension & $168.9 \pm 2.94$ & $167.73 \pm 10.84$ & 0.353 \\
& Flexion & $15.6 \pm 3.22$ & $21.43 \pm 3.67$ & $0.000^{*}$ \\
Thigh & Range of motion & $153.3 \pm 3.69$ & $146.3 \pm 11.37$ & 0.054 \\
& Extension & $121.2 \pm 11.38$ & $128.73 \pm 18.40$ & 0.277 \\
Stifle & Flexion & $17.4 \pm 7.51$ & $25.2 \pm 13.74$ & $0.038^{*}$ \\
& Range of motion & $103.8 \pm 12.09$ & $103.53 \pm 25.12$ & 0.935 \\
& Extension & $154.6 \pm 7.60$ & $149.07 \pm 18.46$ & 0.139 \\
Tarsus & Flexion & $21.1 \pm 2.71$ & $28.23 \pm 5.65$ & $0.001^{*}$ \\
& Range of motion & $133.5 \pm 8.85$ & $120.83 \pm 20.54$ & $0.041^{*}$ \\
& Extension & $167 \pm 4.23$ & $162.27 \pm 11.87$ & $0.037^{*}$ \\
& Flexion & $19.8 \pm 2.97$ & $27.33 \pm 7.71$ & $0.000^{*}$ \\
\hline
\end{tabular}

*significant difference between ages $(\mathrm{p}<0.05)$.

Figure 1. Goniometry in Saanen goats. A - Goniometer positioning of elbow joint in maximum extension in an adult goat. B - Goniometer in tarsal joint of a young goat at maximum extension.

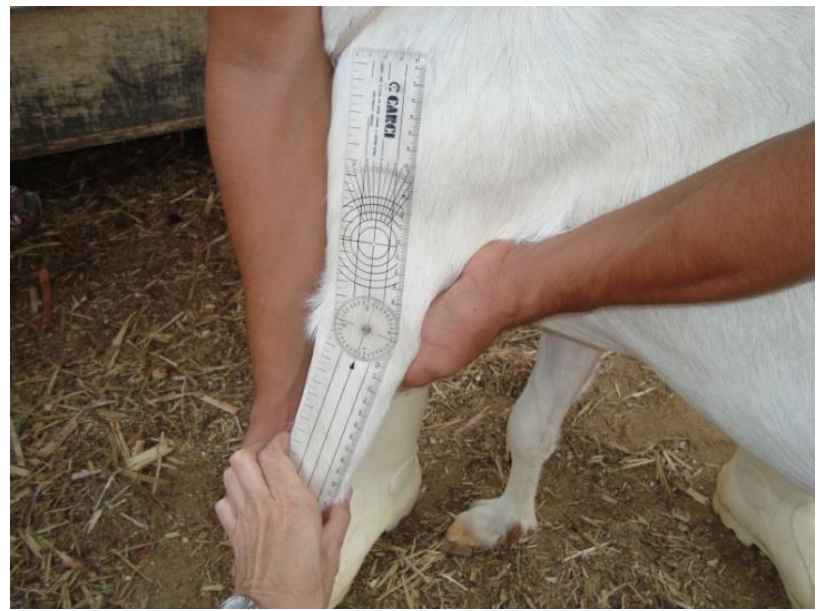

A

\section{Discussion}

The present study measured the angles formed by the major limb joints in flexion and extension. Flexing is the movement of a distal segment member toward a proximal segment (decreased angle between the two segments), whereas

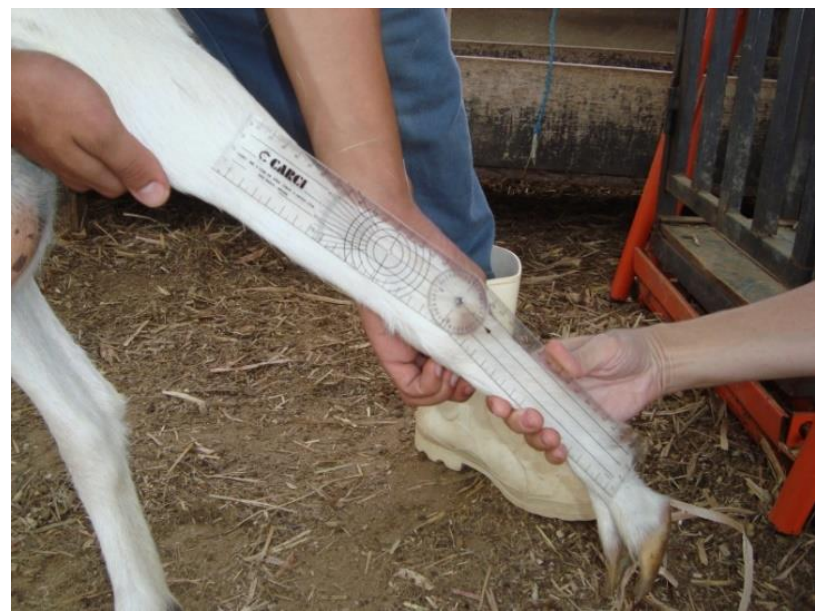

B

extension is the opposite movement, i.e., in which the proximal and distal portions move away from each other (LIEM et al., 2012). The range of motion is calculated as the difference between maximum extension and maximum flexion of the joint, as reported by Conceição et al. (2012). 
In this research, a single evaluator performed all measurements. Watkins et al. (1991) showed goniometric measurements to be highly reliable when performed by the same professional. Conceição et al. (2012) used three evaluators and Govoni et al. (2012) used two; both studies reported no statistical difference between measurements.

As in the present study, Govoni et al. (2012) found, in sheep, goniometric values similar to those in adult goats for certain joints (carpal extension $170 \pm 2$, flexion $20 \pm 1$, and range of motion $150 \pm$ 2 ; extension of elbow $145 \pm 6$, of the stifle $146 \pm 6$, and of the tarsus $163 \pm 3$ ). The differences between other findings in the two studies may be due to the species and weight of the animals; Govoni et al. (2012) used sheep with an average weight of 30.4 $\pm 3.7 \mathrm{~kg}$.

Reduced range of motion was seen in adult animals as compared to the young animals for all joints, but the difference was statistically significant only in the shoulder, elbow, stifle, and tarsus. Soucie et al. (2011) also reported that all ranges of motion decreased with age in human males and females. However, Hady et al. (2015), working with dogs, and Conceição et al. (2012), working with sheep, found no goniometric differences between young and adult animals.

The flaccidity and elasticity of tendons, ligaments, and muscles in young animals versus in adults may have contributed to a greater range of motion in certain joints (shoulder, elbow, stifle, and tarsus). A higher stiffness limits the movements of flexion and extension and consequently, reduces the range of motion. Freemont and Hoyland (2007) listed the main age-dependent factors affecting musculoskeletal tissues: bones become more fragile, cartilage loses resilience, skeletal muscles become weaker, ligaments lose elasticity, and fat is redistributed.

Lacraz et al. (2015) reported that, in mice, muscle stiffness increases with age due to the deposition of extracellular matrix, which influences the microenvironment of myogenic precursor cells (stem cells that act in cell turnover). Sun et al. (2015) mentioned that type V collagen affects the mechanical properties of the anterior cruciate ligament and the long digital flexor tendon. These authors also noted that mutation of type $\mathrm{V}$ collagen leads to Ehlers-Danlos syndrome, for which hypermobility of joints is a primary clinical manifestation. Therefore, because ligament laxity is related to low levels of type $\mathrm{V}$ collagen, studies may show that a low production of type $\mathrm{V}$ collagen in younger animals contributes to the greater range of motion compared to that in older animals that would have a higher deposition of collagen.

Here, it was noted that the greater muscle volume of adult animals influenced the flexion capacity of limbs, a statistically valid observation for all the joints. Young animals reached a more complete flexion, with smaller angles than those in adults. Muscle development enhances movement of joints but when prominent in the flexural faces of the limbs, this development also limits movement because the muscle volume increases. Zhong et al. (2013), in a study on the development of goat skeletal muscle, confirmed that muscle diameter increases steadily with age. Lin et al. (2014) observed that the diameter of type I muscle fibers, as well as the area percentage and diameter of type IIA fibers, were significantly lower in five-monthold sheep than in animals six- or eight-months-old. However, sarcopenia occurs in senescence, which leads to muscle wasting and loss of strength. Loss of motor end plates results in a decrease of innervation which, together with reduced anabolic hormones and increased catabolic agents, increases the muscle loss rate (FREEMONT; HOYLAND, 2007). Therefore, Sabanci and Ocal (2016) in a study of the stifle joint in seven dog breeds, reported that breed differences, body weights, and muscle mass should be taken into consideration during goniometric assessment of stifle function.

With regard to changes resulting from age and pathological alterations, professionals must be alert 
because not only do the connective tissues begin to change with age, but tissue changes occur that have distinct pathological features typically associated with disease (FREEMONT; HOYLAND, 2007). These authors add that it can be difficult to distinguish between the age-related changes and the onset of the disease, thereby complicating the role of the pathologist in diagnosing disease and identifying material for research.

Data reported in this research can be used in evaluation of goats suspected of joint diseases, e.g., caprine arthritis-encephalitis (CAE). Sousa et al. (2014) studied the morphology of joints from healthy goats and those infected with CAE; they noted that the shoulder joint showed a reduction in joint space, an increase in bone density, and other signs of degenerative joint disease. These authors also observed that the carpus joint was not morphologically affected, but the tarsal joint was dramatically affected; no joint space could be seen, an increase in periarticular density was noted, along with swelling and bone sclerosis.

Thus, these goniometric data on the main joints of healthy goats may assist in the clinical prediction of CAE. Tariba et al. (2015) reported that a large percentage (21.9\% to $31.6 \%$ ) of French Alpine goats clinically diagnosed with arthritis were seropositive for CAEV. These authors confirmed a positive association between occurrence of clinical arthritis and seropositivity to CAEV. Lara et al. (2005) corroborated that finding, while also noting that the goats which did not present nosological diagnosis of arthritis were negative for CAEV when tested by immunodiffusion. Therefore, Lascelles et al. (2012) reported that, in cats, palpation and goniometry may be used as a tool to rule out suspected degenerative joint disease, much as has been discussed for CAEV prediction.

\section{Conclusion}

Age-dependent differences in goniometric measurements of the shoulder (flexion and range of motion), elbow (extension, flexion, and range of motion), carpus (flexion), thigh (flexion), stifle (flexion and range of motion), and tarsus (extension, flexion, and range of motion) joints occur in healthy Saanen goats.

\section{References}

ALIEVI, M. M.; SCHOSSLER, J. E.; TEIXEIRA, M. W. Goniometria da articulação tíbio-tarsal após imobilização temporária com fixador esquelético externo em cães. Ciência Rural, Santa Maria, v. 34, n. 2, p. 425-428, mar./ apr. 2004.

ARAÚJO, F. A. P.; RAHAL, S. C.; MACHADO, M. R. F.; TEIXEIRA, C. R.; LORENA, S. E. R. S.; BARBOSA, L. Goniometria dos membros pélvicos de pacas (Cuniculus paca) criadas em cativeiro. Pesquisa Veterinária Brasileira, Rio de Janeiro, v. 29, n. 12, p. 1004-1008, dec. 2009.

BATISTA, L. H.; CAMARGO, P. R.; AIELLO, G. V.; OISHI, J.; SALVINI, T. F. Avaliação da amplitude articular do joelho: correlação entre as medidas realizadas com o goniômetro universal e no dinamômetro isocinético. Revista Brasileira de Fisioterapia, São Carlos, v. 10, n. 2, p. 193-198, 2006.

COLVILLE, T.; BASSERT, J. M. Clinical anatomy and physiology for veterinary technicians: laboratory manual. $2^{\text {th }}$ ed. Philadelphia: Elsevier Health Sciences, 2008. $496 \mathrm{p}$.

CONCEIÇÃO, R. T.; RAHAL, S. C.; AGOSTINHO, F. S.; TEIXEIRA, C. R.; ARAÚJO, F. A. P.; MONTEIRO, F. O. B. Goniometria dos membros torácicos e pélvicos de ovinos em duas faixas etárias. Pesquisa Veterinária Brasileira, Rio de Janeiro, v. 32, n. 8, p. 812-816, aug. 2012.

DIFFAY, B. C.; MCKENZIE, D.; WOLF, C.; PUGH, D. G. Abordagem e exame de ovinos e caprinos. In: PUGH, D. G. Clínica de ovinos e caprinos. São Paulo: Roca, 2005. p. 1-19.

DUKES, W. O. R. Fisiologia dos animais domésticos. 12. ed. Rio de Janeiro: Guanabara Koogan; 2007. 954 p.

DYCE, K. M.; SACK, W. O.; WENSING, C. J. G. Tratado de anatomia veterinária. 4. ed. São Paulo: Elsevier, 2010. $872 \mathrm{p}$.

FRANDSON, R. D.; WILKE, W. L.; FAILS, A. D. Anatomia e fisiologia dos animais de fazenda. 7. ed. Rio de Janeiro: Guanabara Koogan, 2011. 472 p. 
FREEMONT, A. J.; HOYLAND, J. A. Morphology, mechanisms and pathology of musculoskeletal ageing. Journal of Pathology, Edinburgh, v. 211, n. 2, p. 252259, jan. 2007.

GAIAD, T. P.; SILVA, M. B.; SILVA, G. C. A.; CAROMANO, F. A.; MIGLINO, M. A.; AMBRÓSIO, C. E. Physical therapy assessment tools to evaluate disease progression and phenotype variability in Golden Retriever muscular dystrophy. Research in Veterinary Science, Rome, v. 91, n. 2, p. 188-193, oct. 2011.

GETTY, R. SISSON/GROSSMAN: anatomia dos animais domésticos. 5. ed. Rio de Janeiro: Guanabara Koogan, 1986. $2000 \mathrm{p}$.

GILLETTE, R. L.; ANGLE, T. C. Recent developments in canine locomotor analysis: a review. The Veterinary Journal, Atlanta, v. 178, n. 2, p. 165-176, nov. 2008.

GOVONI, V. M.; RAHAL, S. C.; AGOSTINHO, F. S.; CONCEIÇÃO, R. T.; TSUNEMI, M. H.; EL-WARRAK, A. O. Goniometric measurements of the forelimb and hindlimb joints in sheep. Veterinary and Comparative Orthopaedics and Traumatology (VCOT), Stuttgart, v. 25, n. 4, p. 297-300, apr. 2012.

GREGORY, L.; SILVA, L. C. L. C.; ANGELINI, M.; LARA, M. C. C. S. H.; FRANCHINI, M. L.; RIZZO, E. H.; CARDOSO, M. V.; BENESI, F. J.; CASTRO, R. S. Avaliação clínica de caprinos acometidos por artrite. Diferencial entre artrite viral (CAE) e bacteriana (Mycoplasma spp.) em dois casos atendidos no hospital veterinário da FMVZ-USP. Arquivo Instituto Biológico, São Paulo, v. 73, n. 2, p. 247-249, 2006.

HADY, L. L.; FOSGATE, G. T.; WEH, J. M. Comparison of range of motion in Labrador Retrievers and Border Collies. Journal of Veterinary Medicine and Animal Health, Los Angeles, v. 7, n. 4, p. 122-127, apr. 2015.

LACRAZ, G.; ROULEAU, A. J.; COUTURE, V.; SÖLLRALD, T.; DROUIN, G.; VEILLETTE, N.; GRANDBOIS, M.; GRENIER, G. Increased stiffness in aged skeletal muscle impairs muscle progenitor cell proliferative activity. PLOS ONE, San Francisco, v. 10, n. 8, p. 1-13, 2015. Available at: <http://journals.plos. org/plosone/article?id=10.1371/journal.pone.0136217>. Accessed at: 2 abr. 2016.

LANGENSKIÖLD, A.; MICHELSSON, J. E.; VIDEMAN, T. Osteoarthritis of the knee in the rabbit produced by immobilization. Acta Orthopaedica Scandinavica, Oxfordshire, v. 50, n. 1, p. 1-14, feb. 1979.
LARA, M. C. C. S. H.; BIRGEL JUNIOR, E. H.; GREGORY, L.; BIRGEL, E. H. Aspectos clínicos da artrite-encefalite dos caprinos. Arquivo Brasileiro de Medicina Veterinária e Zootecnia, Belo Horizonte, v. 57, n. 6, p. 736-740, 2005.

LASCELLES, B. D. X.; DONG, Y. H.; MARCELLINLITTLE, D. J.; THOMPSON, A.; WHEELER, S.; CORREA, M. Relationship of orthopedic examination, goniometric measurements, and radiographic signs of degenerative joint disease in cats. BMC Veterinary Research, London, v. 8, p. 10, jan. 2012.

LIEM, K. L.; BEMIS, W. E.; WALKER JUNIOR, W. F.; GRANDE, L. Anatomia funcional dos vertebrados: uma perspectiva evolutiva. Trad. EZ2 Translate. 3. ed. norteamericana. São Paulo: Cengage Learning, 2012. 529 p.

LIN, S.; ZAI-QIONG, L.; QIAN, Y.; XIAO-BING, M.; XIAO-BING, H.; YE, J. Analyzing the muscle fiber characteristics of Sunit sheep. Science and Technology of Food Industry, Beijing, v. 6, p. 22, 2014.

SABANCI, S. S.; OCAL, M. K. Comparison of goniometric measurements of the stifle joint in seven breeds of normal dogs. Veterinary and Comparative Orthopaedics and Traumatology (VCOT), Stuttgart, v. 29, n. 3, p. 214-219, may 2016.

SOUCIE, J. M.; WANG, C.; FORSYTH, A.; FUNK, S.; DENNY, M.; ROACH, K. E.; BOONE, D. Range of motion measurements: reference values and a database for comparison studies. Haemophilia, Washington, v. 17, n. 3, p. 500-507, may 2011.

SOUSA, V. R.; SOUSA, F. C. A.; SILVA-FILHO, O. F.; RICI, R. E. G.; DINIZ, A. N.; MOURA, L. S.; ALVES, J. J. R. P.; SOUSA-JÚNIOR, A.; MIGLINO, M. A.; SOUSA, J. M.; MORAES-JÚNIOR, F. J.; ALVES, F. R. Comparative study by computed radiography, histology and scanning electron microscopy of the articular cartilage of normal goats and in chronic infection with Caprine-Arthritis-Encephalitis Virus. Microscopy Research and Technique, Genoa, v. 77, n. 1, p. 11-16, jan. 2014.

SUN, M.; CONNIZZO, B. K.; ADAMS, S. M.; FREEDMAN, B. R.; WENSTRUP, R. J.; SOSLOWSKY, L. J.; BIRK, D. E. Targeted deletion of collagen V in tendons and ligaments results in a classic Ehlers-Danlos syndrome joint phenotype. The American Journal of Pathology, New York, v. 185, n. 5, p. 1436-1447, may 2015. 
TARIBA, B.; KOSTELIĆ, A.; SALAMON, D.; ROIĆ, B.; BENIĆ, M.; PRVANOVIĆ BABIĆ, N.; SALAJPAL, $\mathrm{K}$. Prevalence of caprine arthritis encephalitis virus in association with clinical arthritis in six production farms of French Alpine goats in North-Western Croatia. Poljoprivreda, Osijek, v. 21, n. 1, p. 135-137, 2015. Supplement.

UHTHOFF, H. K.; JAWORSKI, Z. F. G. Bone loss in response to long term imobilisation. Journal of Bone and Joint Surgery, Minneapolis, v. 60-B, n. 3, p. 420-429, aug. 1978.
WATKINS, M. A.; RIDDLE, D. L.; LAMB, R. L.; PERSONIUS, W. J. Reliability of goniometric measurements and visual stimates of knee range of motion obtained in a clinical setting. Physical Therapy, Boston, v. 71, n. 2, p. 90-96, feb. 1991.

ZHONG, T.; JIN, P. F.; DONG, E. N.; WANG, L. J.; ZHANG, H. P. Caprine sex affects skeletal muscle profile and MRFs expression during postnatal development. Animal Science Journal, Champaign, v. 84, n. 5, p. 442448, may 2013. 